\title{
Regularities of electrochemical cleaning of oil-contaminated soils
}

\author{
Nikolay S. SHULAEV, Valeriya V. PRYANICHNIKOVA, Ramil R. KADYROV $\square$ \\ Ufa State Petroleum Technological University, Branch in the City of Sterlitamak, Sterlitamak, Russia
}

\begin{abstract}
How to cite this article: Shulaev N.S., Pryanichnikova V.V., Kadyrov R.R. Regularities of electrochemical cleaning
\end{abstract} of oil-contaminated soils. Journal of Mining Institute. 2021. Vol. 252, p. 937-946. DOI: 10.31897/PMI.2021.6.15

\begin{abstract}
Electrochemical cleaning of oil-contaminated soils is a promising area of environmental safety, as it can be easily organized even in locations remote from settlements. For this purpose, a power source and a system of electrodes are necessary as equipment. It is possible to use an electric generator if there are no power supply lines nearby. The material of electrodes affects the features of redox processes, which can affect the energy consumption and the degree of soil cleansing from oil or oil products. Therefore, the correct choice of electrode materials is one of the important tasks in the field of engineering electrochemical methods of purification. Changes in the main parameters (humidity, temperature, degree of acidity) in an oil-contaminated model soil, similar in composition to one of the oil fields, were investigated. Measurements of parameters when using graphite and metal electrodes were carried out at several fixed sections of the interelectrode space depending on the treatment time. The established patterns of parameter changes in the purification of oil-contaminated soils allow us to draw conclusions about the stages of the electrochemical process, its speed, and energy efficiency. The results obtained form a basis for designing industrial facilities for soil treatment.
\end{abstract}

Key words: electrochemical method; oil-contaminated soil; electrode; electric current; parameters

Acknowledgment. The study was carried out with the financial support of the Russian Foundation for Basic Research within the framework of scientific project N 18-29-24041.

Introduction. The electrochemical method of exposure is promising for solving environmental problems, in particular, for cleaning soils from oil products $[9,13,14]$, organochlorine compounds $[5,26]$ and other pollutants $[3,4,7]$. The features of this method include: high cleaning efficiency, the possibility of combining with other remediation methods [20, 19,33], mobility due to the use of compact equipment and ease of deployment in almost any area, even far from populated areas [16, 29, 34]. During the treatment of soils with electric current, they are also strengthened [12]. Due to these features, the field of application of electrochemical cleaning is expanding [11, 27, 30].

The main equipment for electrochemical cleaning is a source of electricity and a system of electrodes (anodes and cathodes) immersed in the soil to the depth of contamination $[8,22]$. If there are power lines near the site of pollution, you can connect a source of electricity and electrode systems to it, if there is no such line, a power generator is needed. The source power is selected due to the energy consumption for cleaning and the operating time [15, 17]. It is possible to use generators running on fossil fuels, as well as on renewable energy sources - solar or wind [25].

The electrodes are installed in the ground in accordance with the most efficient layout that provides a high degree of cleaning at the lowest possible energy consumption. When a direct electric current is passed through oil-contaminated soil, redox processes occur, which are typical for the electrolysis of solutions [23, 24, 28]. Composition of the electrolytic liquid and the material of the 
anode determine the type of oxidation and reduction reactions [21, 35]. If inert anodes (insoluble electrode) are used, then electronic exchange will occur without destroying the electrode [2]. If an active anode (soluble electrode) is used, then it itself is able to oxidize during electrolysis. Thus, the material of the electrodes significantly affects the efficiency and energy consumption of cleaning and determines the service life. Based on this, it is relevant to evaluate the efficiency of electrochemical processes depending on the materials of the electrodes, the selection of which will improve the efficiency of cleaning contaminated soils at a given processing time interval with the lowest possible energy costs.

The aim of the work is to establish regularities of change in the main parameters (humidity, temperature, degree of acidity) of oil-contaminated soils in the interelectrode space depending on the processing time when using graphite and metal electrodes, which is necessary when designing industrial plants.

It was established in $[6,31,32]$ that when an electric current is passed, the concentration of oil products decreases according to an exponential law:

$$
C(t)=C_{0} e^{-\alpha I t}=C_{0} e^{-\alpha q(t)},
$$

where $C_{0}$ is the initial concentration of oil products, $\mathrm{kg} / \mathrm{m}^{3} ; I$ - electric current, $\mathrm{A} ; q(t)$ is the charge passed through the soil, $\mathrm{C} ; \alpha$-coefficient depending on the type of oil-contaminated soil and the mass of oil products in the cleaned area, $\mathrm{C}^{-1}$,

$$
\alpha=\frac{1}{C_{0} V q_{s p}},
$$

$V$ is the volume of contaminated soil, $\mathrm{m}^{3} ; q_{s p}$ - specific charge required to remove $1 \mathrm{~kg}$ of oil products (for clay soil $-6.3 \cdot 10^{6}$, black earth soil $-9.6 \cdot 10^{6}$, loam $-9.3 \cdot 10^{6}$, sandy soil $-13.4 \cdot 10^{6} \mathrm{C} / \mathrm{kg}[1,10]$ ).

Methodology. Experiments were carried out with model soil containing salt solutions $(\mathrm{NaCl}$, $\mathrm{CaCl}_{2}, \mathrm{MgCl}_{2}$, etc.) and oil [18]. Oil pollution was \% of the mass per $1 \mathrm{~kg}$ of soil.

A model soil weighing $1.5 \mathrm{~kg}$ was placed in a plexiglas in the form of a rectangular parallelepiped (Fig.1). The electrodes were sunk into the ground.

It is most important to measure humidity, degree of acidity, temperature at three points: at the cathode, anode and in the middle between the electrodes. In experiments, measurements of these parameters were periodically carried out at a given current at five points of the interelectrode space in order to obtain a more detailed characteristic of the distribution of parameters over distance, including for further modeling.

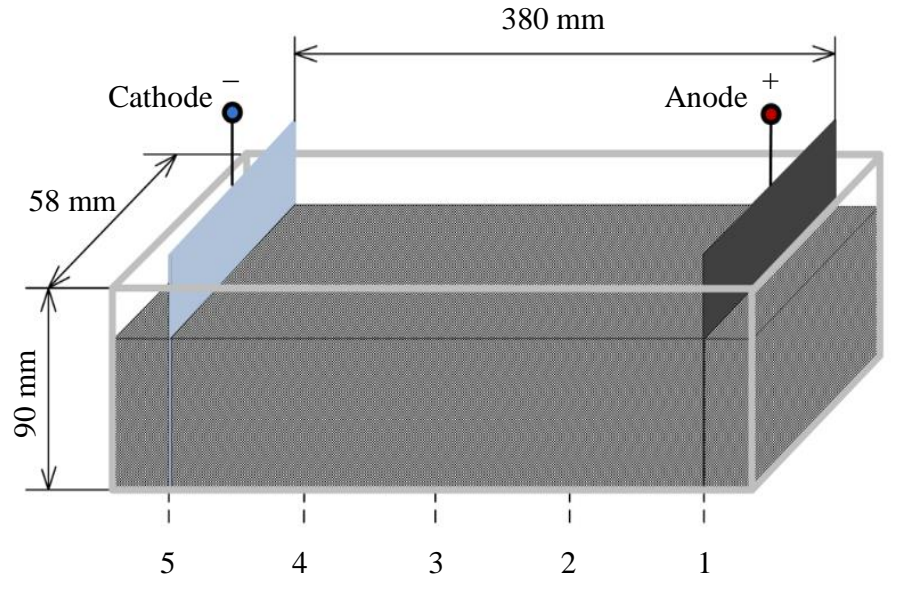

Fig.1. Cell with model soil and electrodes

In the experiments, the electric current between the electrodes was maintained at a constant value (0.8 A), which made it possible to determine the main regularities of change in the measured parameters in the interval of $360 \mathrm{~min}$ (their control and registration were carried out every $30 \mathrm{~min}$ ).

One of the objectives of the research was to study the influence of the electrode material on the nature of electrochemical cleaning process. In the first case, a graphite pair was used as electrodes, in the second case, a steel cathode (SC) and a titanium-based ruthenium oxide anode (TROA). 
Results and their discussion. Measurement of the voltage applied to the graphite electrodes at a constant electric current of 0.8 A made it possible to record its drop from 61.9 to $38.5 \mathrm{~V}$ in the first $90 \mathrm{~min}$ and a gradual increase to $52 \mathrm{~V}$ by $360 \mathrm{~min}$ (Fig.2).

When measuring the voltage between the metal electrodes SC and TROA, a constant current of $0.8 \mathrm{~A}$ was also maintained. In this case, the voltage decreased from 71 to $40.4 \mathrm{~V}$ for the first $90 \mathrm{~min}$, then slowly increased to 47 to $360 \mathrm{~min}$ (Fig.2).

The decrease in voltage in the first $90 \mathrm{~min}$ in experiments with graphite and metal electrodes (SC-TROA) is explained by the fact that during this period there is an increase in conductivity associated with a redistribution of soil moisture concentration as a result of electrokinetic processes. In the time interval $90<\mathrm{t}<360 \mathrm{~min}$, when using graphite electrodes, the voltage increases faster and reaches a higher value than when using metal electrodes, therefore, in the second case, the integral conductivity is higher, and energy consumption is lower. To further maintain a constant current value when using graphite electrodes, in contrast to metal ones, a higher voltage of the external power source will be required due to the increased overvoltage of hydrogen and oxygen evolution. At a higher overvoltage, the electrochemical process slows down, the conductivity decreases, and unproductive consumption of electricity for the polarization of the electrodes increases.

From an analysis of the redistribution of humidity in cells with graphite and metal (SC-TROA) electrodes, it can be noted that the humidity at the cathode and anode increases up to 90 min, after which it decreases. In the electrode zones, the humidity values are much higher than in the central interelectrode zone (Fig.3). Evaluating the humidity profiles separately for different electrode materials, one can notice that the maximum humidity values with graphite electrodes are in the cathode and anode areas, and in the middle part of the cell, the humidity tends to a minimum (Fig.3, $a$ ); in the case of SC-TROA electrodes, the moisture minimum is shifted from the center to the cathode (Fig.3, b), therefore, in this region, the liquid evaporation is more intense, which leads to an increase in electrical resistance.

When studying the temperature fields in a cell with graphite electrodes, it can be seen that the maximum values are achieved in the central region between the electrodes (third point), the minimum values are in the anode and cathode regions (Fig.4, $a$ ). The temperature in the cell with metal electrodes (SC-TROA) has maximum values at the fourth point, and minimum values - in the anode region (Fig.4, $b$ ). These indications are confirmed by the data of thermal imaging (Fig.5) performed by the RGK TL-80 device. An increase in temperature in the central interelectrode region is explained by a decrease in conductivity in the zone under consideration.

The obtained temperature profile data indicate that in the case of using graphite electrodes, the soil resistivity in the central region is higher than in the near-electrode regions, and when using SC-TROA electrodes, the highest soil resistivity shifts in time from the central part to the near-cathode region.

The readings of the degree of soil acidity change from weakly acidic to strongly acidic at all points, then by the end of the measurements, an alkaline medium in the cathode area is formed (Fig.6). In the case of using SC-TROA electrodes, the alkaline medium is formed in a shorter time interval. 


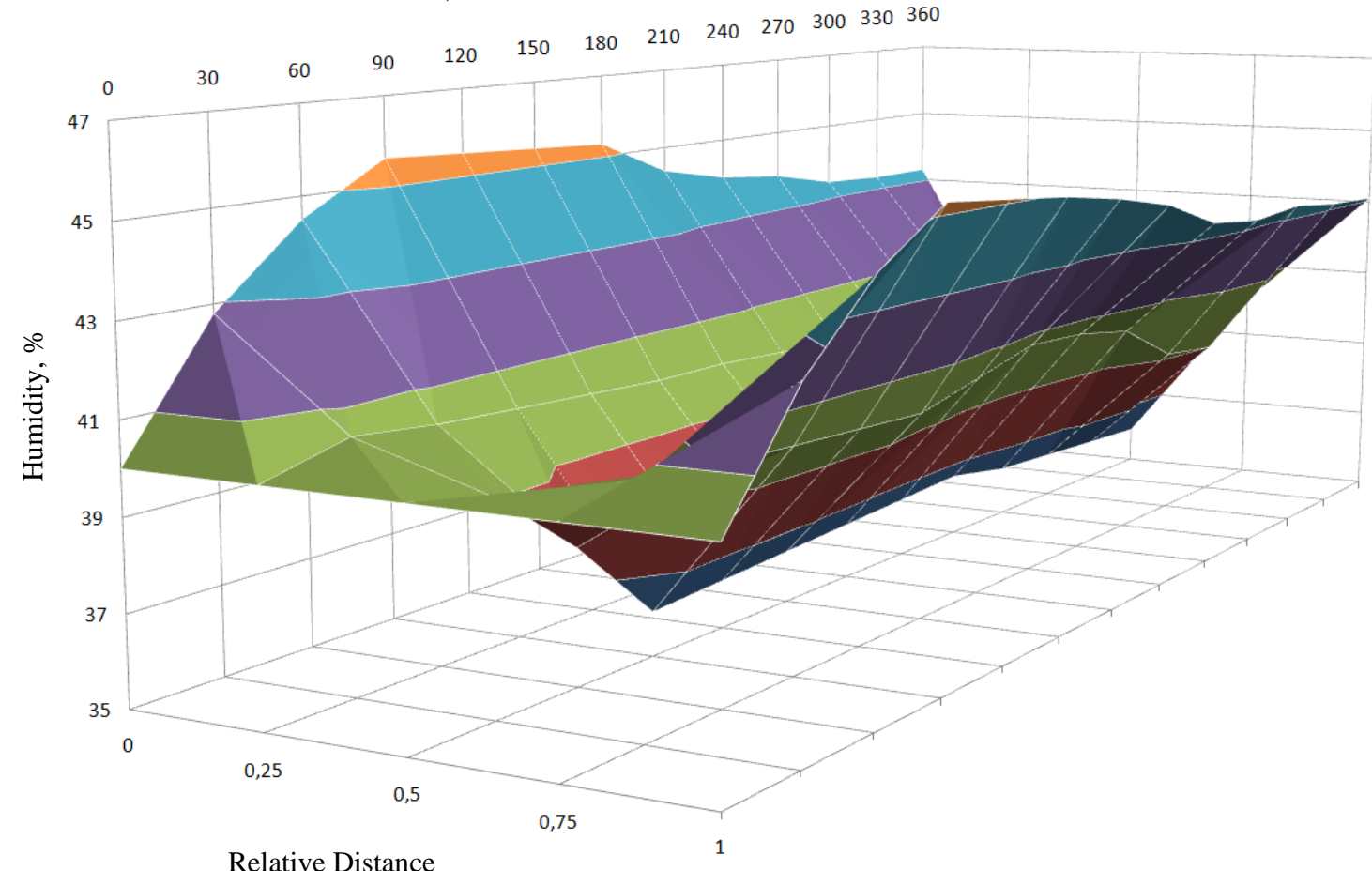

$b$

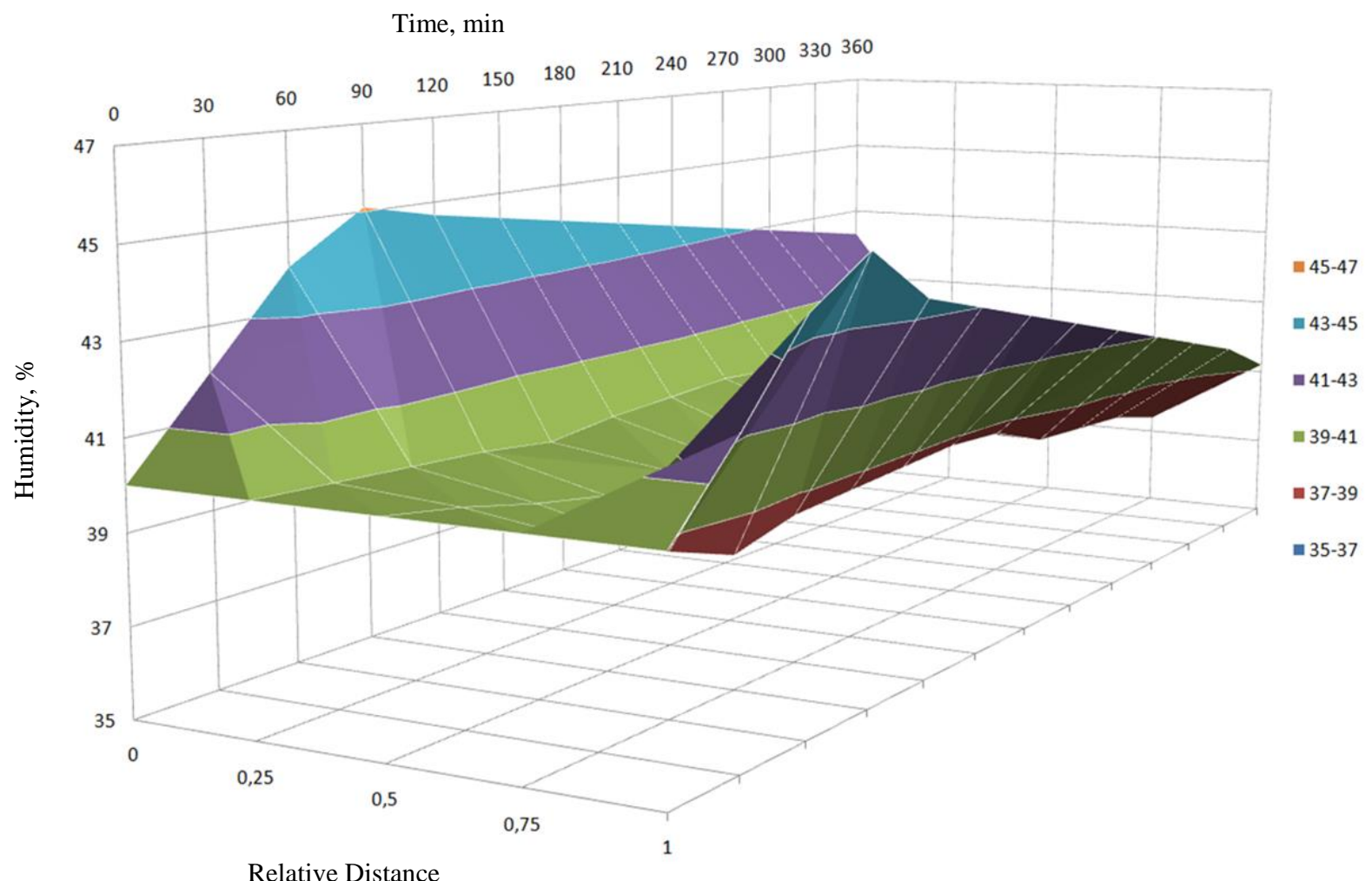

Relative Distance

Fig.3. Humidity change over time at different distances from the electrodes: $a$ - with graphite electrodes; $b-\mathrm{SC}$ and TROA 


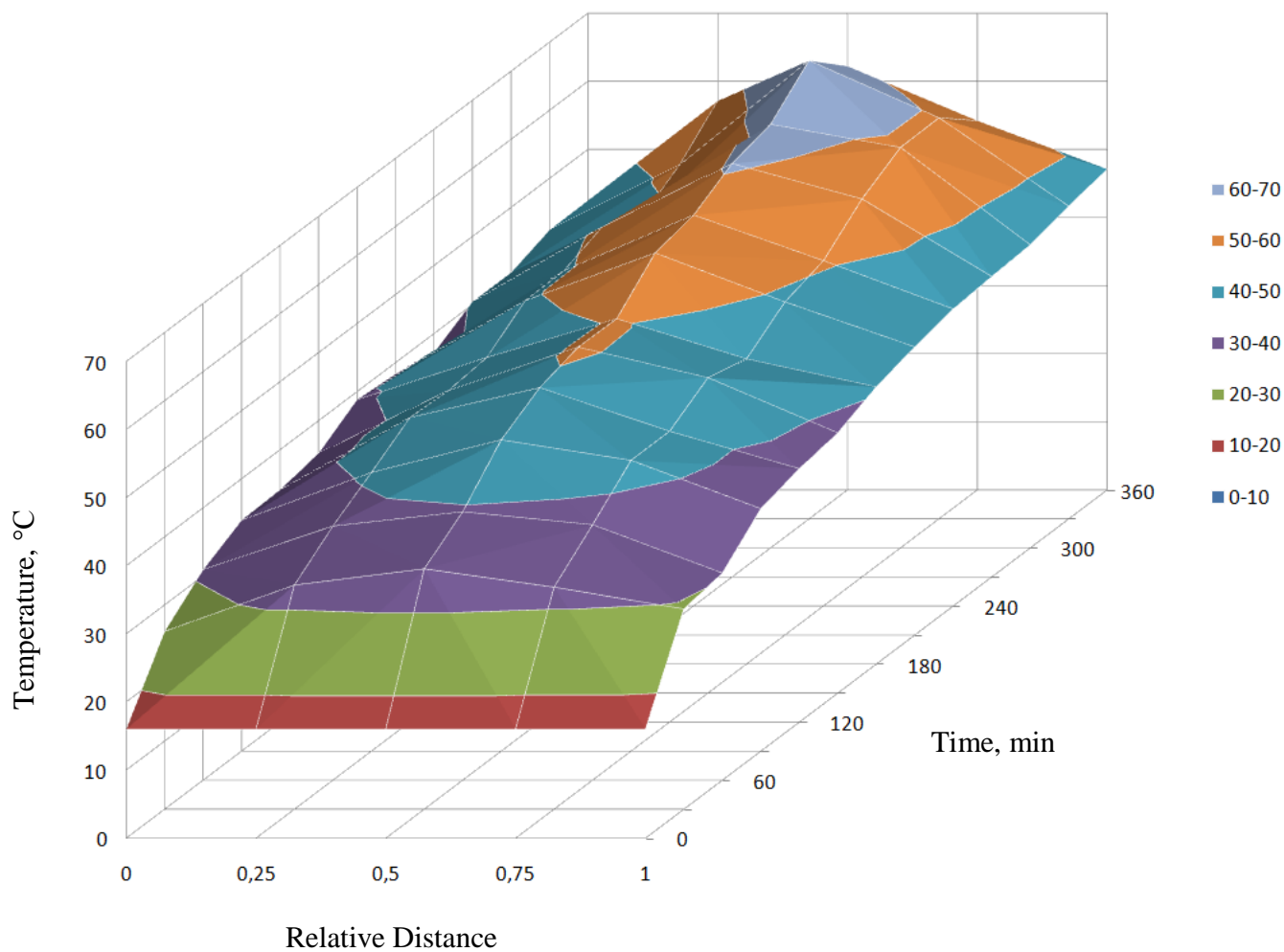

$b$

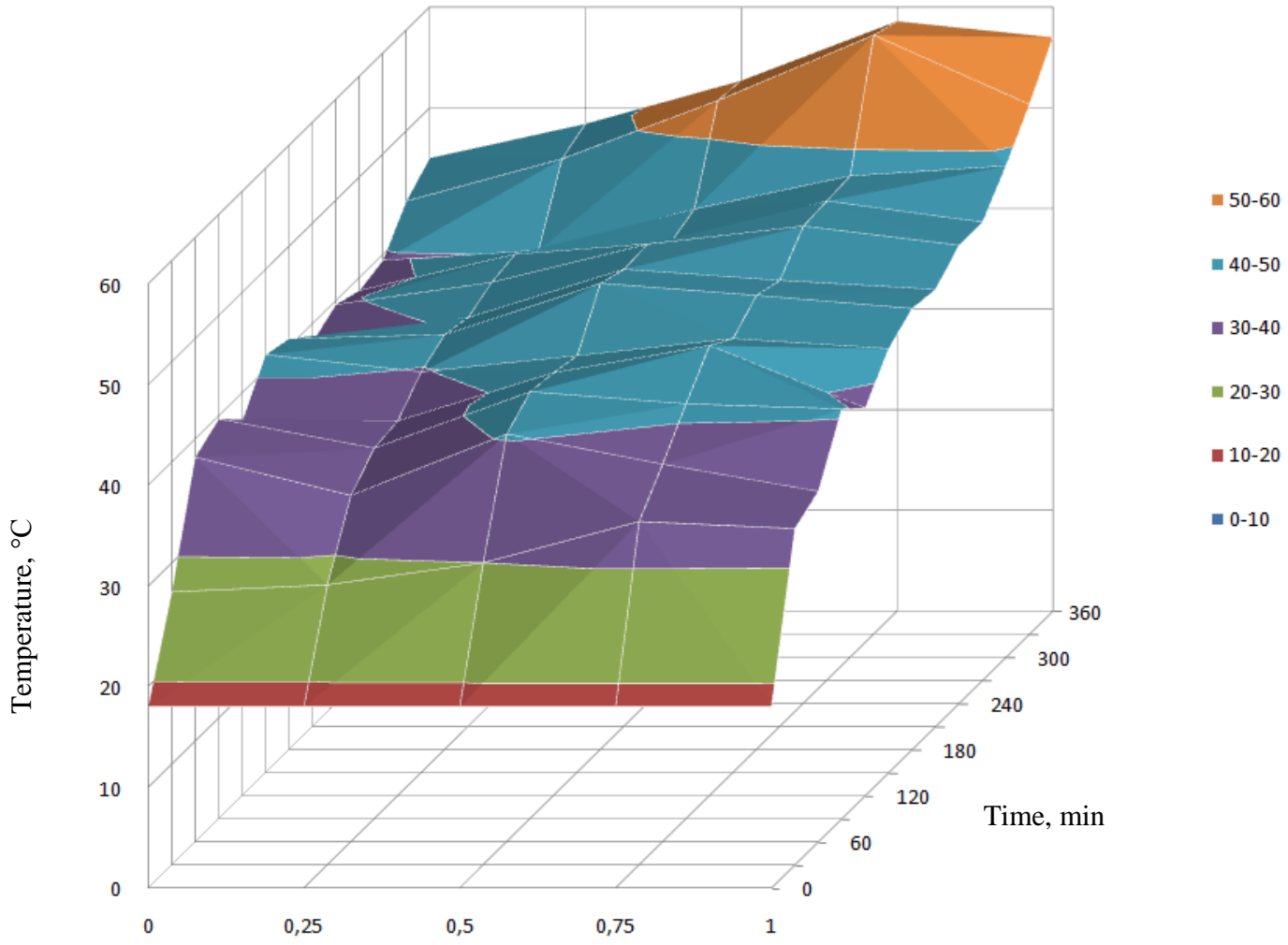

Relative Distance

Fig.4. Temperature change in time at different distances from the electrodes: $a$ - with graphite electrodes; $b-\mathrm{SC}$ and TROA 


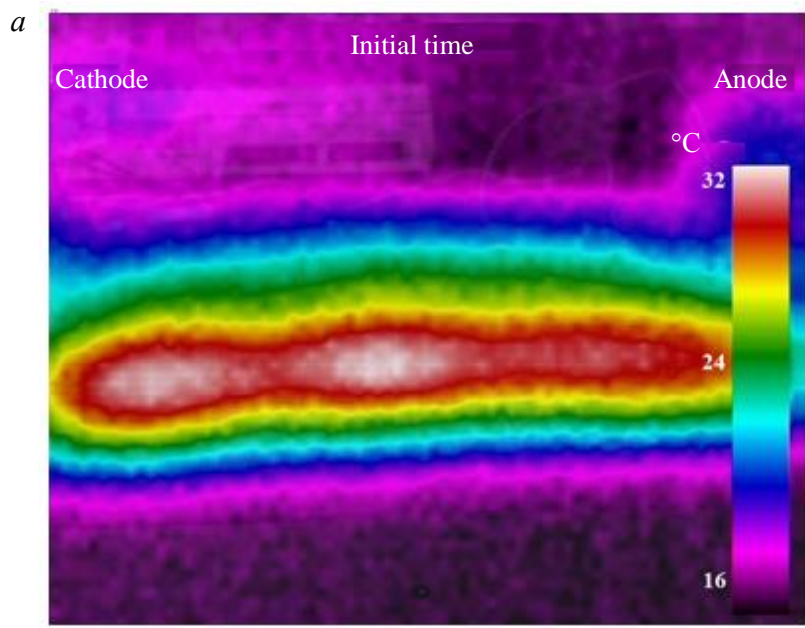

$b$

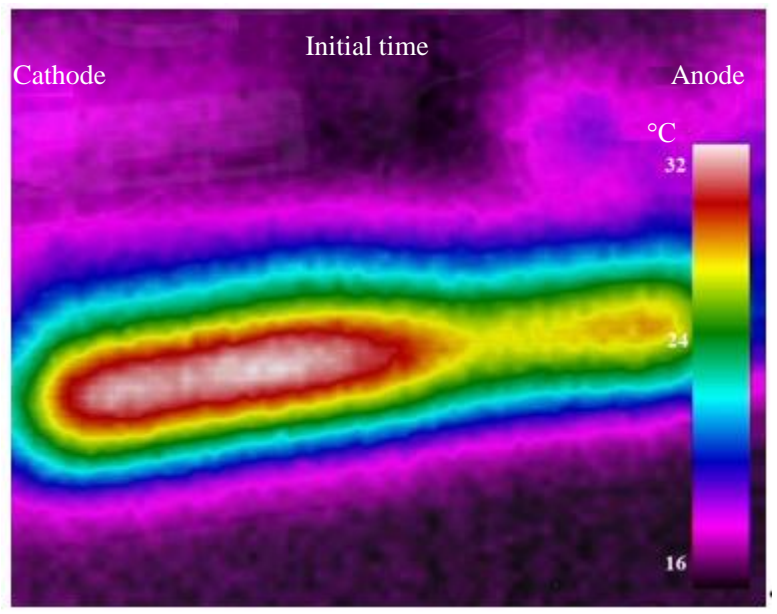

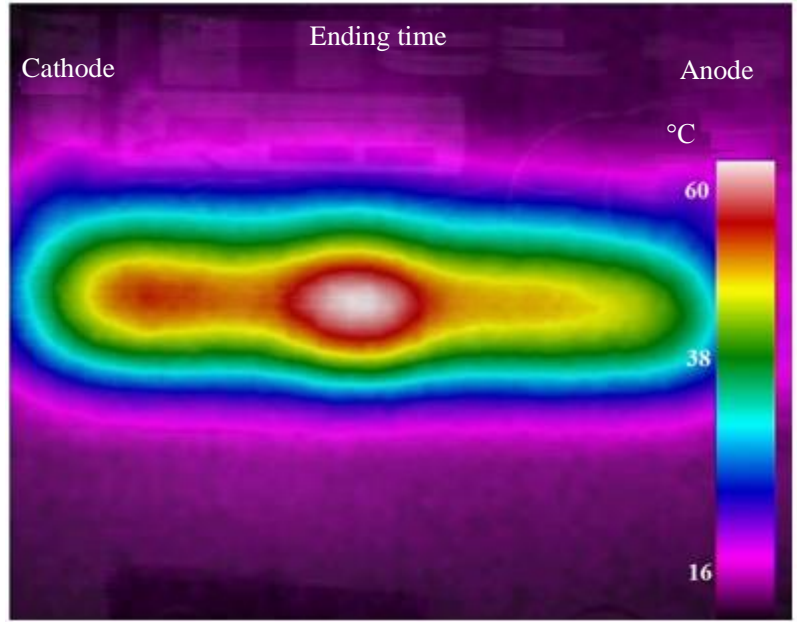

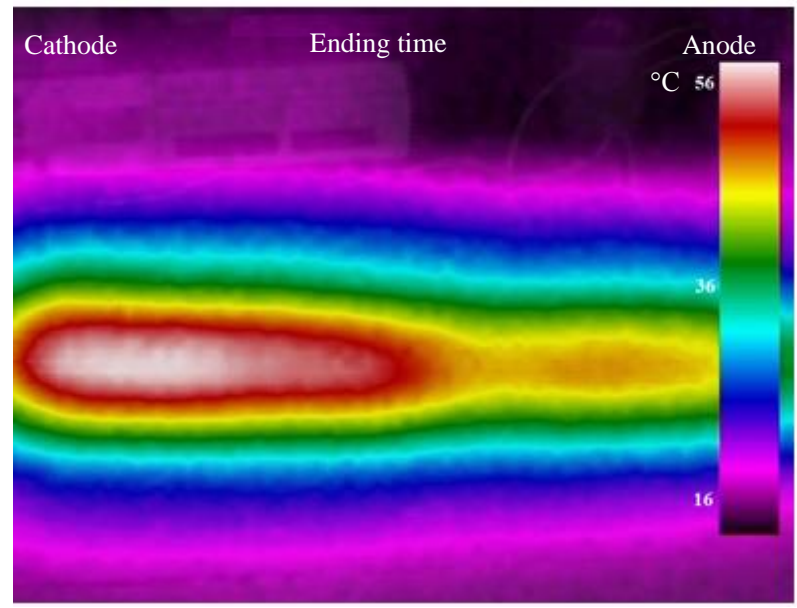

Fig.5. Temperature distribution during thermal imaging at the initial and final moments of time: $a$ - with graphite electrodes; $b-\mathrm{SC}$ and TROA

For the analysis of electrochemical processes, a temperature profile between the electrodes was chosen (Fig.7). Based on the above graphs, the temperature distribution has a parabolic character. If the cell is with graphite electrodes, then the temperature at 180 and 360 min reaches a maximum in the central part of the cell, and it is minimal in the region of the electrodes. In the case of SC-TROA electrodes, the top of the parabola is shifted to the cathode for 180 and $360 \mathrm{~min}$, reaching a maximum value in the near-cathode region.

The given research results can be explained by the fact that the model soil is saturated with salt solutions, mainly chlorides, which creates conditions for electrolysis. After voltage is applied to the electrodes, an intensive movement of ions occurs. Since graphite and ruthenium oxide plates were used as anodes for the experiments, the oxidation proceeded similarly to the electrolysis of solutions with an inert anode. As a result, $\mathrm{Cl}^{-}$ions are oxidized on the anode with the release of $\mathrm{Cl}_{2}$ and water with the release of $\mathrm{O}_{2}$ and the formation of $\mathrm{H}^{+}$. Also, in the area of the anode, the concentration of $\mathrm{HCl}$ gradually increases, which subsequently leads to a decrease in soil $\mathrm{pH}$ in most of the cell. A wide band of highly acidic environment creates favorable conditions for cleaning the soil from oil pollutants (the degree of cleaning of oil-contaminated soil is more than $71 \%$ ). However, in this case, soil acidification occurs, therefore, it is periodically possible to change the polarity of the electrodes to approach the neutral $\mathrm{pH}$ level.

Since the solution contains a relatively large amount of active metal cations $\mathrm{Ca}, \mathrm{Na}, \mathrm{Mg}$, they are not reduced at the cathode, but are concentrated near it in the form of alkaline solutions. At the cathode, only hydrogen ions are reduced from water with gas evolution. 
$a$

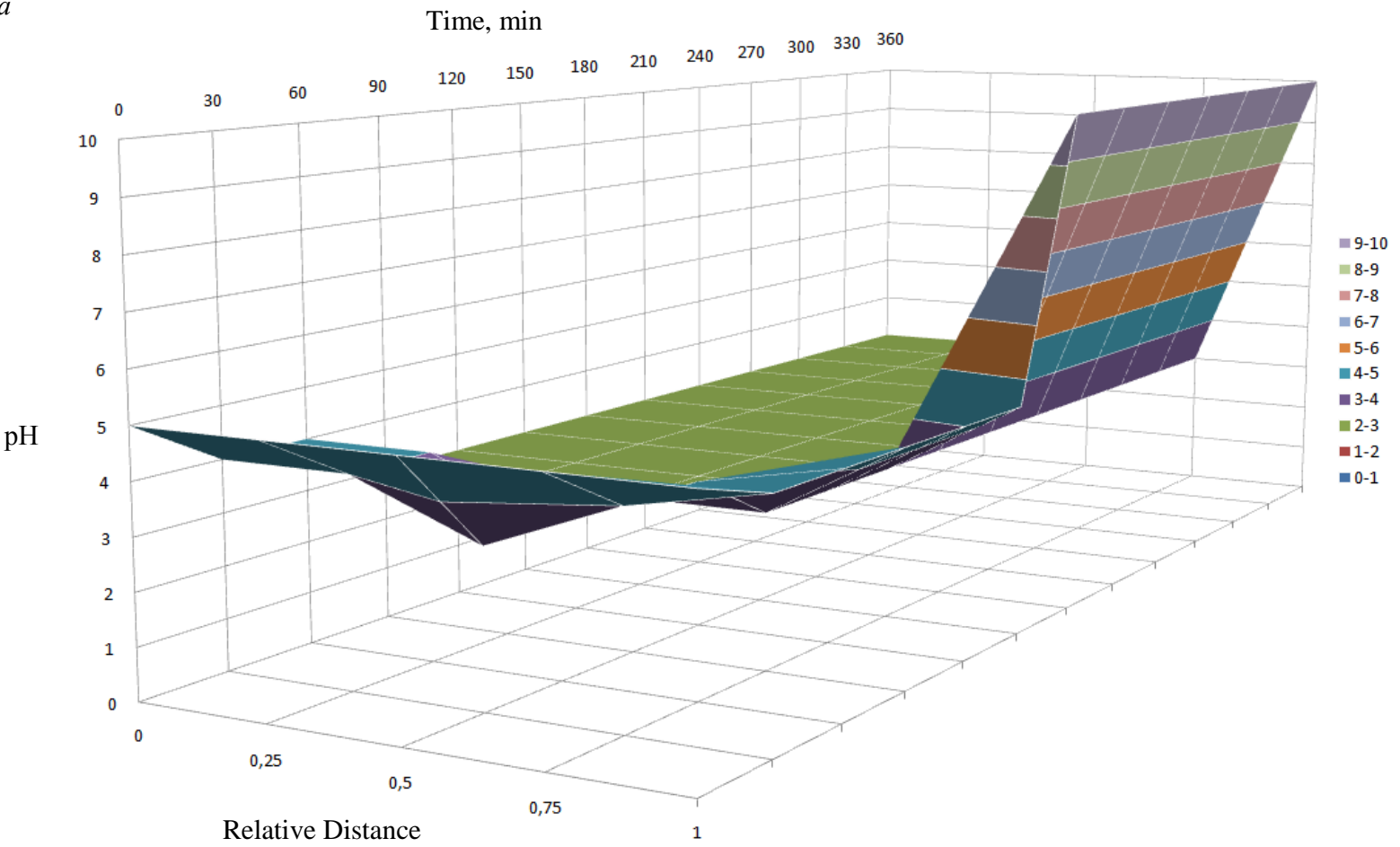

$b$

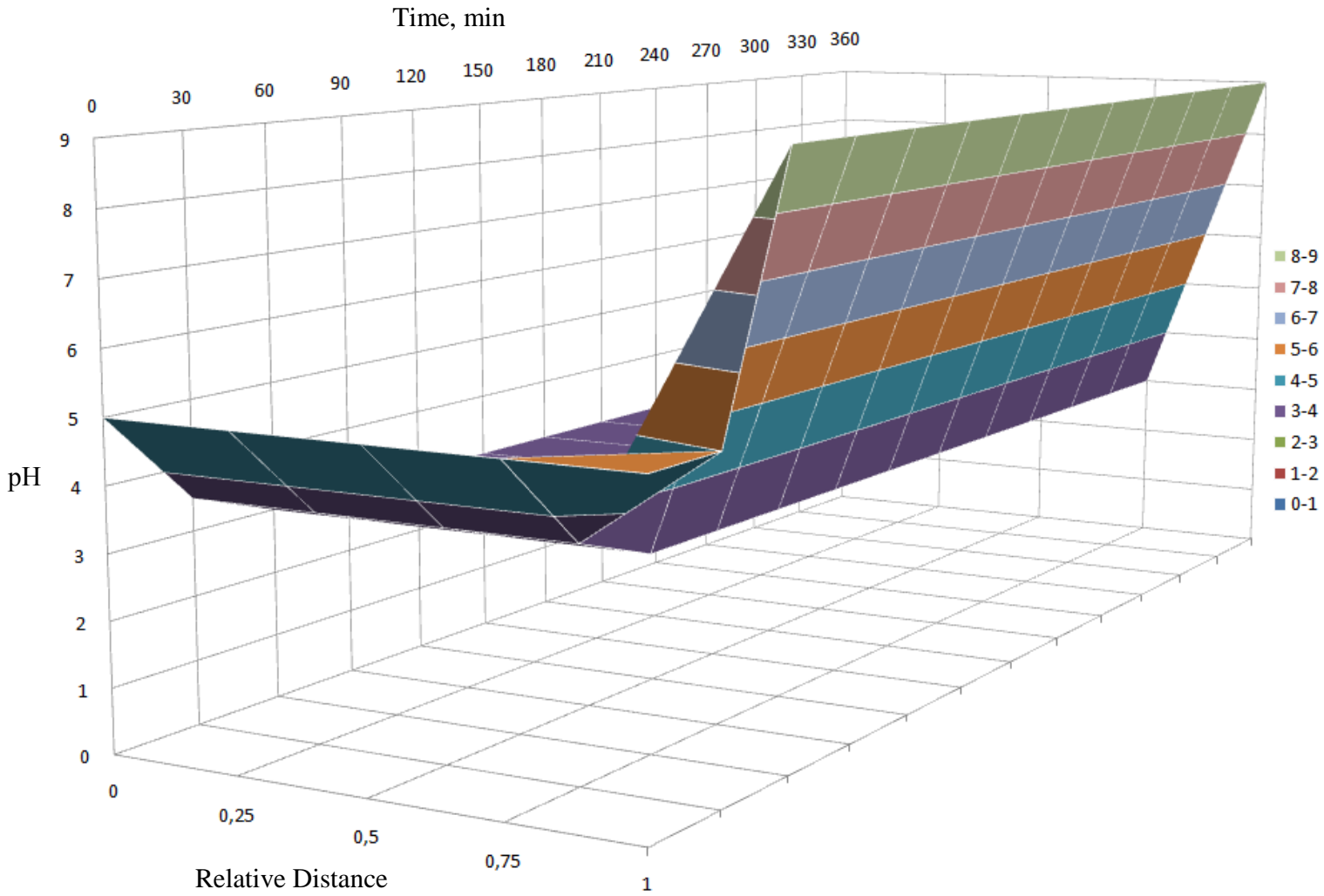

Fig.6. Change in $\mathrm{pH}$ over time at different distances from the electrodes: $a$ - with graphite electrodes; $b-\mathrm{SC}$ and TROA 
$a$

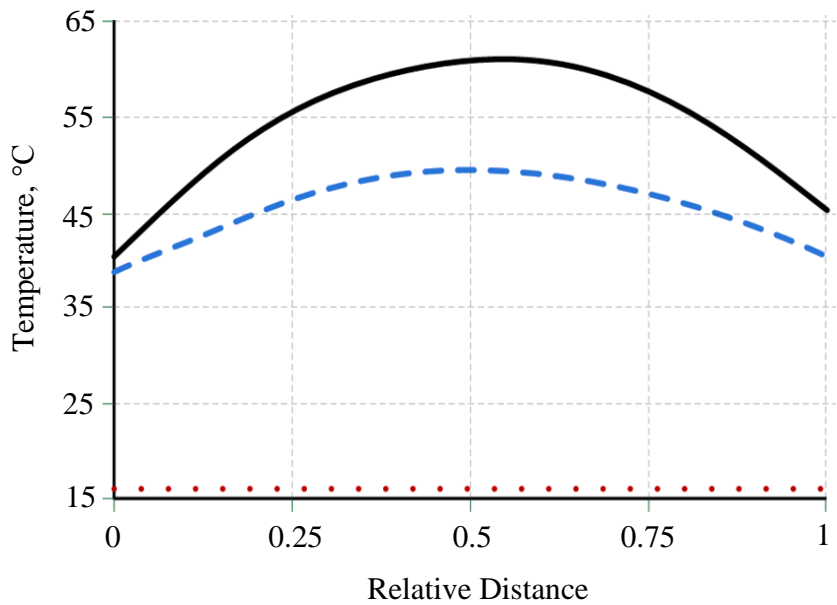

$b$

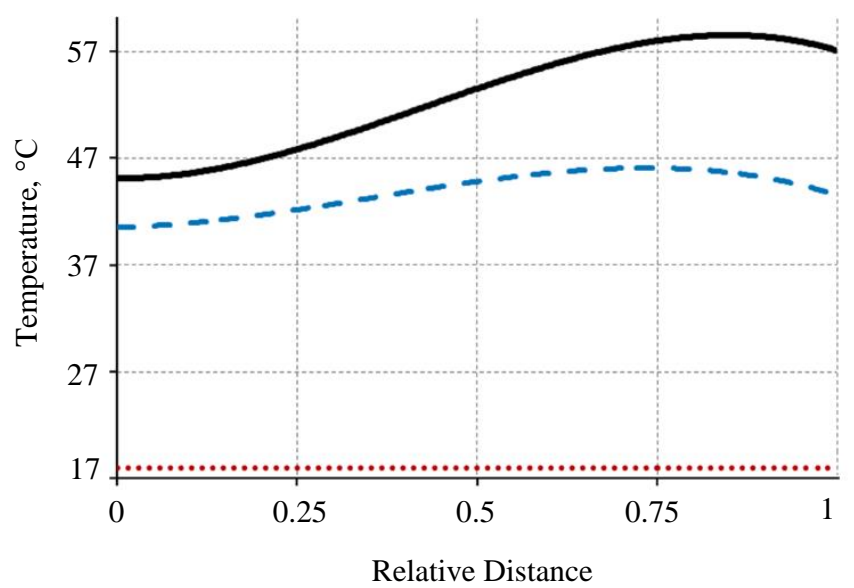

.... $1=-2 \longrightarrow$

Fig.7. Change in temperature at a relative distance from the electrodes (from the anode $(0.0)$ to the cathode $(1.0)$ at different points in time: $a$ - with graphite electrodes; $b-\mathrm{SC}$ and TROA $1-$ at $t=0 ; 2-180 ; 3-360 \mathrm{~min}$
Similar results were presented in $[3,15$, 29 ], but for other soils and the degree of pollution.

The presence on the graphs of areas with a minimum value of moisture characterizes drying, which in some cases is used to strengthen soils. In such regions, the conductivity is low, which contributes to Joule heating, as evidenced by the temperature distribution graphs. Lower temperatures are observed in the anodic regions than in the cathodic ones. When using graphite electrodes, the maximum temperature is reached in the middle of the cell, and when using SCTROA, in the near-cathode region. This is due to the characteristics of the electrode materials: SC and TROA have lower overvoltage values than graphite ones, which increases the overall conductivity; the overvoltage of TROA is less than that of the SC, so the conductivity near the anode is higher compared to the near-cathode region, as evidenced by the graphs of temperature fields and soil moisture.

Conclusion. From the analysis of experimental studies with graphite and metal electrodes (SC-TROA) it was found that:

- the voltage at the initial stage drops to a minimum, then slowly increases, however, when using metal electrodes (SC-TROA), the voltage increases at a slower rate, which indicates lower energy consumption and an increase in soil resistivity;

- humidity on the cathode and anode increases up to a certain point in time, after

which it decreases; humidity on the electrodes during the entire time interval was higher than in the interelectrode zone (when using graphite electrodes, the humidity tends to a minimum in the middle part of the cell, and when using SC and TROA, the humidity minimum is shifted from the center to the cathode);

- the temperature in the cell with graphite electrodes has the highest values in the middle between the electrodes, the lowest - at the anode and cathode; the temperature at the final stage in the cell with metal electrodes (SC-TROA) has the highest values in the cathode region, the lowest in the anode region;

- soil $\mathrm{pH}$ changes from slightly acidic to strongly acidic at all points, but from a certain point in time, an alkaline environment forms near the cathode (when using SC-TROA electrodes, it forms earlier), in the remaining parts of the cell with the studied soil, the environment remains strongly acidic, and the degree of acidity approaches increases towards the anode.

The results of experimental studies of the parameters of oil-contaminated soil (temperature, humidity, degree of acidity) in time and at different distances from the cathode and anode allow to draw conclusions about the main stages of the electrochemical process and its speed. The use of metal 
(SC-TROA) electrodes shows that they are more energy efficient than graphite ones, and also have the longest service life.

The revealed regularities of electrochemical processes should be taken into account when designing industrial installations for soil treatment.

\section{REFERENCES}

1. Shulaev N.S., Pryanichnikova V.V., Kadyrov R.R. et al. Impact of electric current on soils contaminated with oil products. Butlerovskie soobshcheniya. 2020. Vol. 61. N 2, p. 132-138. DOI: 10.37952/ROI-jbc-01/20-61-2-132 (in Russian).

2. Zhelovitskaya A.V., Dresvyannikov A.F. Electrode Materials Used to Generate Reactive Radicals in Wastewater Treatment. Vestnik tekhnologicheskogo universiteta. 2017. Vol. 20. N 4, p. 107-112 (in Russian).

3. Korolev V.A., Nesterov D.S. Results of the international conference EREM-2017 - Electrokinetic cleaning of soils from pollution. Inzhenernye izyskaniya. 2017. N 10, p. 14-22. DOI: 10.25296/1997-8650-2017-10-14-22 (in Russian).

4. Korolev V.A. Electrochemical cleaning of soils from ecotoxicants: results and prospects. Vestnik Moskovskogo universiteta. Seriya 4. Geologiya. 2008. N 1, p. 13-20 (in Russian).

5. Lysenko L.L. Improvement of the method of electrokinetic cleaning of fine clay soils. Ekologicheskaya khimiya. 2014. Vol. 23. N 1, p. 13-21 (in Russian).

6. Meshalkin V.P., Shulaev N.S., Pryanichnikova V.V. Experimental and theoretical engineering of an energy-efficient electrochemical process for cleaning soil from oil pollution. Doklady Rossiiskoi akademii nauk. 2020. Vol. 491, p. 15-19. DOI: 10.31857/S2686953520020053 (in Russian).

7. Prostov S.M. Physical prerequisites for cleaning soil massifs from pollution by the electrochemical method. Vestnik Kuzbasskogo gosudarstvennogo tekhnicheskogo universiteta. 2014. N 2, p. 136-139 (in Russian).

8. Shabanov E.A., Prostov S.M., Gerasimov O.V. Laboratory studies of the processes of electrochemical cleaning of soils in the bases of operated buildings and structures from oil products. Vestnik Tomskogo gosudarstvennogo arkhitekturno-stroitelnogo universiteta. 2019. Vol. 21. N 4, p. 168-180. DOI: 10.31675/1607-1859-2019-21-4-168-180 (in Russian).

9. Shabanov E.A., Prostov S.M. Full-scale tests of the method of controlled electrochemical cleaning of soil from oil pollution. Part III. Electrophysical monitoring of the pollution zone. Vestnik Kuzbasskogo gosudarstvennogo tekhnicheskogo universiteta. 2017. N 3, p. 80-86 (in Russian).

10. Shulaev N.S., Pryanichnikova V.V., Kadyrov R.R., Ovsyannikova I.V. et al. Electrochemical cleaning of soils with different concentrations of oil pollution using a single source of electrical voltage. Nauka i tekhnologii truboprovodnogo transporta nefti i nefteproduktov. 2020. Vol. 10. N 6, p. 674-680. DOI: 10.28999/2541-9595-2020-10-6-674-680 (in Russian).

11. Rada E., Istrate I., Ragazzi M. et al. Analysis of Electro-Oxidation Suitability for Landfill Leachate Treatment through an Experimental Study. Sustainability. 2016. Vol. 5. Iss. 9, p. 149-172. DOI: 10.1201/b20005-13

12. Gingine V., Shah R.P., Koteswar R., Hari Krishna P. A review on study of Electrokinetic stabilization of Expansive soil. International Journal on Earth Science and Engineering. 2013. Vol. 2, p. 176-181. DOI: 10.13140/2.1.2809.4086

13. Asadollahfardi G., Rezaee M. Electrokinetic remediation of diesel-contaminated silty sand under continuous and periodic voltage application. Environmental Engineering Research. 2018. Vol. 24. Iss. 3, p. 456-462. DOI: 10.4491/eer.2018.301

14. Cameselle C., Reddy K.R. Development and enhancement of electro-osmotic flow for the removal of contaminants from soils. Electrochimica Act. 2012. Vol. 86, p. 10-22. DOI: 10.1016/j.electacta.2012.06.121

15. Cocarta D.M., Istrate I.A., Streche C., Dumitru D.M. Removal of Total Petroleum Hydrocarbons from Contaminated Soils by Electrochemical Method. World Academy of Science, Engineering and Technology International Journal of Environmental and Ecological Engineering. 2017. Vol. 11. N 5, p. 469-473. DOI: 10.5281/zenodo.1131870

16. Ferreira M.B., Solano Sales A.M., Santos E.V. et al. Coupling of Anodic Oxidation and Soil Remediation Processes: A Review. Materials. 2020. Vol. 13. Iss. 19. N 4309. DOI: 10.3390/ma13194309

17. Streche C., Cocarta D., Istrate I., Badea A. Decontamination of Petroleum-Contaminated Soils Using The Electrochemical Technique: Remediation Degree and Energy Consumption. Scientific Reports. 2018. Vol. 8. N 3272. DOI: 10.1038/s41598-018-21606-4

18. Meshalkin V.P., Shulaev N.S., Chelnokov V.V. et al. Determination of electrical parameters for the electrochemical treatment of soils contaminated with oil. IOP Conference Series: Materials Science and Engineering. 2019. Vol. 537. Iss. 6, p. 62-69. DOI: $10.1088 / 1757-899 X / 537 / 6 / 062069$

19. Crognale S., Cocarta D., Streche C., D'Annibale A. Development of laboratory-scale sequential electrokinetic and biological treatment of chronically hydrocarbon-impacted soils. New Biotechnology. 2020. Vol. 58, p. 38-44. DOI: 10.1016/j.nbt.2020.04.002

20. Bernardo Sabino da Silva E., Lima M., Oliveira M. et al. Electrokinetic Treatment of Polluted Soil with Petroleum Coupled to an Advanced Oxidation Process for Remediation of Its Effluent. International journal of electrochemical science. 2016. Vol. 12, p. 1247-1262. DOI: $10.20964 / 2017.02 .18$

21. Trellu C., Chakraborty S., Nidheesh P.V., Oturan M.A. Environmental Applications of Boron-Doped Diamond Electrodes: 2. Soil Remediation and Sensing Applications. ChemElectroChem. 2019. Vol. 6, p. 2143-2156. DOI: 10.1002/celc.201801877

22. Ferrarese E., Andreottola G. Application of Electrochemical Techniques for the Remediation of Soils Contaminated With Organic Pollutants. Proceedings of the Annual International Conference on Soils, Sediments, Water and Energy. 2010. Vol. 13, p. 343-372.

23. Ganiyu S.O., Gamal M. El-Din Insight into in-situ radical and non-radical oxidative degradation of organic compounds in complex real matrix during electrooxidation with boron doped diamond electrode: A case study of oil sands process water treatment. Applied Catalysis B: Environmental. 2020. Vol. 279. N 119366. DOI: 10.1016/j.apcatb.2020.119366 
24. Ganiyu S.O., Martínez-Huitle C.A. Nature, Mechanisms and Reactivity of Electrogenerated Reactive Species at Thin-Film Boron-Doped Diamond (BDD) Electrodes during Electrochemical Wastewater Treatment. ChemElectroChem. 2019. Vol. 6. Iss. 9, p. 2379-2392. DOI: $10.1002 /$ celc.201900159

25. Ganiyu S.O., Martinez-Huitle C.A., Rodrigo M.A. Renewable energies driven electrochemical wastewater/soil decontamination technologies: A critical review of fundamental concepts and applications. Applied Catalysis B: Environmental. 2020. Vol. 270. N 118857. DOI: $10.1016 /$ j.apcatb.2020.118857

26. Gomes H.I., Dias-Ferreira C., Ribeiro A.B. Electrokinetic remediation of organochlorines in soil: enhancement techniques and integration with other remediation technologies. Chemosphere. 2012. Vol. 87. Iss. 10, p. 1077-1090. DOI: $10.1016 /$ j.chemosphere.2012.02.037

27. Istrate I., Apostol T., Badea A. An alternative to the treatment of leachate contaminated soil. Ecoterra. 2014. Vol. 11. N 2, p. $78-84$.

28. Jamaly S., Giwa A., Hasan S.W. Recent improvements in oily wastewater treatment: Progress, challenges, and future opportunities. Journal of environmental sciences. 2015. Vol. 37, p. 15-30. DOI: 10.1016/j.jes.2015.04.011

29. Korolev V.A., Romanyukha O.V., Abyzova A.M. Electrokinetic remediation of oil-contaminated soils. Journal of Environmental Science and Health. Part A: Toxic/Hazardous Substances and Environmental Engineering. 2008. Vol. 43. Iss. 8, p. 876-880. DOI: 10.1080/10934520801974384

30. Lawrence M.Z., Kenneth J.W., Pamukcu S. Electrochemical Geo-Oxidation (ECGO) treatment of Massachusetts New Bedford Harbor sediment PCBs. Electrochimica Acta. 2020. Vol. 354. N 136690. DOI: 10.1016/j.electacta.2020.136690

31. Pryanichnikova V.V., Shulaev N.S., Kadyrov R.R. The Electrochemical Cleaning of Various Types of Soils Contaminated with Reservoir Water and Oil. IOP Conference Series: Earth and Environmental Science. 2019. Vol. 272. Iss. 2. N 022039. DOI: 10.1088/1755-1315/272/2/022039

32. Pryanichnikova V.V., Shulaev N.S., Bykovsky N.A., Kadyrov R.R. The electrochemical method of oil-contaminated soil remediation. Key Engineering Materials. 2017. Vol. 743, p. 314-318. DOI: 10.4028/www.scientific.net/KEM.743.314

33. Dos santos E., Saez C., Canizares P. et al. Treatment of ex-situ soil-washing fluids polluted with petroleum by anodic oxidation, photolysis, sonolysis and combined approaches. Chemical Engineering Journal. Vol. 310. Part 2, p. $581-588$. DOI: $10.1016 /$ j.cej.2016.05.015

34. Tican A., Istrate I. Electro-oxidation treatment used for the remediation of organic polluted soils. UPB Scientific Bulletin, Series D: Mechanical Engineering. 2014. Vol. 76. Iss. 4, p. 215-222.

35. Zhou W., Rajic L., Chen L. Activated carbon as effective cathode material in iron-free Electro-Fenton process: Integrated $\mathrm{H}_{2} \mathrm{O}_{2}$ electrogeneration, activation, and pollutants adsorption. Electrochimical Acta. 2018. Vol. 296, p. 317-326. DOI: $10.1016 /$ j.electacta.2018.11.052

Authors: Nikolay S. Shulaev, Doctor of Engineering Sciences, Professor, https://orcid.org/0000-0002-3595-6948 (Ufa State Petroleum Technological University, Branch in the City of Sterlitamak, Sterlitamak, Russia), Valeriya V. Pryanichnikova, Candidate of Engineering Sciences, Associate Professor, https://orcid.org/0000-0001-8997-5186 (Ufa State Petroleum Technological University, Branch in the City of Sterlitamak, Sterlitamak, Russia), Ramil R. Kadyrov, Candidate of Engineering Sciences, Associate Professor, r_kadyrov@mail.ru, https://orcid.org/0000-0001-6665-9375 (Ufa State Petroleum Technological University, Branch in the City of Sterlitamak, Sterlitamak, Russia).

The authors declare no conflict of interests. 